\title{
INNOVATION STAGES AND ORGANIZATIONAL RESOURCES AT MIDSIZED COMPANIES IN BRAZIL
}

\author{
Priscila Rezende da Costa \\ Universidade Nove de Julho, São Paulo, Brasil \\ priscilarc@uninove.br
}

\section{Geciane Silveira Porto}

Faculdade de Economia, Administração e Contabilidade de Ribeirão Preto

\author{
Universidade de São Paulo \\ geciane@usp.br
}

\section{ABSTRACT}

The structuring of innovation stages and analysis of organizational resources that catalyze innovative solutions is not only essential to the understanding of innovative behavior at midsized companies, but also to the raising of issues that may be of use when ideating public policies in support of innovation at midsized Brazilian companies. Given this framework, the purpose of this study is to analyze the status of innovation at midsized companies in Brazil. This was a triangular research that adopted the lifting sequential method effectively covering a sample made up of 50 mid-sized companies, scattered throughout 12 different economic sectors. Primary and secondary data were employed in the study. This was respectively collected via semi-structured interviews with managers and directors over the phone or via Skype and from journals, conference proceedings, journals and databases. During primary data collection, interviewers examined interviewee responses (content analysis) and subsequently defined corporate scores for each type of organizational resource using a 5-point scale, whereby 1 represented the highest level of organizational resource incipient application/presence, 3 an intermediate level and 5 the highest. Field research results (descriptive and multivariate analysis of data) revealed that the innovative profile of studied midsized companies is characterized by the 
intermediate stage in terms of product and processes innovation and by the embryonic stage when considering organizational innovation. This generally indicates that for product and process innovation, the prevailing strategy is technological differentiation and product and process development, whilst typically the innovation process is both mixed and closed. In as much as organizational innovation is concerned, core strategies include conducting technological benchmarks and monitoring market trends, whilst the innovation process is linear and nonsystematic.

Key-words: Midsized companies. Innovation. Organizational Resources.

\section{RESUMO}

A estruturação de uma visão geral dos estágios de inovação e análise de recursos organizacionais potencializador de soluções inovadoras são essenciais não só para a compreensão do comportamento inovador das empresas de médio porte, mas podem ser úteis para as políticas públicas de apoio à inovação na média empresa brasileira. Perante este cenário, o estudo tem como objetivo analisar o estágio de inovação de empresas de médio porte no Brasil. A pesquisa foi triangular e o método foi o levantamento, atingindo uma amostra efetiva de 50 empresas de médio porte, envolvendo 12 diferentes setores da economia. Os dados utilizados no estudo foram primário e secundário, coletados, respectivamente, por meio de entrevistas semi-estruturadas com gestores e diretores por telefone ou via skype e a partir de periódicos, anais de eventos, revistas e bases de dados. Na coleta de dados primários o entrevistador analisou as respostas dos entrevistados (análise de conteúdo) e, posteriormente, foi definida a pontuação da empresa para cada tipo de recurso organizacional usando uma escala de cinco pontos, em que 1 representa o nivel mais baixo de aplicação / presença do recurso na organização, o nível intermediário 3 e 5 o nível mais alto. Os resultados de pesquisa de campo (análise descritiva e multivariada de dados), revelou que o perfil inovador das empresas de médio porte estudadas pode ser caracterizado 


\section{FUTURE SRJ}

FUTURE STUDIES RESEARCH JOURNAL: TRENDS AND STRATEGIES

pelo estágio intermediário para a inovação de produtos e processos e estágio embrionário para a inovação organizacional. Constatou-se ainda que para a inovação de produtos e processos a estratégia predominante é a diferenciação tecnológica e desenvolvimento de produtos e processos, além disso, o processo de inovação é misto e fechado. Quanto à inovação organizacional a estratégia essencial é a realização de benchmarking tecnológica e o acompanhamento das tendências de mercado, sendo o processo de inovação linear e não-sistemático.

Palavras-chave: Empresas de médio porte. Inovação. Recursos organizacionais. 


\section{INTRODUCTION}

The concept of innovation in itself has broadened to the extent that currently the challenge no longer lies in the mere generation of product and process innovations but rather in the continuous search for innovative organizational solutions and similarly, ideations in the field of Marketing. Initially, innovative process analysis primarily focused on the linear generation of new knowledge. This approach has also evolved and currently comprises the development of open and dynamic ways to produce, implement, distribute and share knowledge, skills and technologies.

Although facts involving midsized companies are not as widely acknowledged from both a social and an economic standpoint as those pertaining to micro, small and large companies, effectively it was precisely this segment that ventured and produced some of the most significant, challenging cases of innovation in the country, namely: Bematch, Fotosensores, Reivax and Opto. Thus, structuring an overview involving innovation stages and the analysis of organizational resources found to potentialize innovative solutions is mandatory, not only for the theoretical and empirical understanding of this type of business, but also so as to raise issues, which may prove to be useful for public policies that further support innovation at average-sized companies in Brazil. Given this context, the purpose of the study is to analyze the innovation stage of medium sized companies in Brazil. This research specifically seeks to (a) offer generic stages for innovation, (b) characterize the studied midsized companies and their innovation stages, and (c) verify if organizational resources impact these company's innovation stages.

It is important to clarify that the term innovation herein employed comprises (a) the development of a new product or significant improvement of an existing product (b) the implementation of a new or significantly improved production or distribution method, and/or (3) the implementation a new organizational method, involving significant changes in internal and external management practices (Organization for Economic Cooperation and Development, 2005). In turn, midsized businesses are industrial enterprises (according to the CNAE classification of Brazilian Geography and Statistics Institute - IBGE) holding 100 to 499 employees. Finally, the term organizational resources refers to standards, practices and management routines which coordinate corporate tangible and intangible resources. 


\section{THEORETICAL FRAMEWORK}

\subsection{INNOVATION: CONCEPT AND MANAGEMENT}

By resorting to the essence of neoclassical and evolutionary theories, one may better comprehend the historical evolution of innovation as a theme. The neoclassical school aligns itself with the perspective of unlimited rationality within human behavior and with an expected balance between economic relations. In turn, innovation would be a natural consequence of a, homogeneous, linear and natural in the course of productive activity mechanical process, i.e., internal to the firm's production system, which results in average production cost depreciation (Bell \& Pavitt, 1993; Dosi, 1982; Freeman, 1994).

In contrast, the evolutionary school is marked by the flexibility expectations involving rationality and ignores the role results play in terms of maximizing objectiveness. Change processes in turn present a dynamic, cumulative and non-linear character that acknowledges active competition between productive agents (Freeman, 1995; Gava, 2007; Kline \& Rosenberg, 1986). Therefore, if on one hand classical perspectives focused on corporate innovation, the evolutionary theory sought to investigate the true standing of businesses and understand their learning and innovation capabilities: strategies, adaptation practices, integration and skills and resource reconfiguration (Lundvall, 1992; Nelson \& Winter, 1977; Teece \& Pisano, 1994; Winter, 1988).

Attempts to present a historical overview of innovation as a subject matter require special mention of the economist Joseph Schumpeter's contribution in pioneering the positioning of innovation as prime source of dynamism within capitalist systems. Schumpeter (1988) pinpointed the existing relationship between technological innovation and long economic growth cycles which arise from increased investment shortly after the introduction of most significant innovations. According to this author, capitalism was developing given incentives for the emergence of entrepreneurs, i.e. capitalists or creative inventors were responsible for prosperity waves presented by the system. Furthermore, to his understanding, every innovation implies in "creative destruction" whereby novelty does not arise from that which is old, but rather springs alongside and surpasses the same. Accordingly, innovations are thus characterized by the introduction of new and more efficient productive combinations or changes in production functions, which effectively serve as the fundamental impulse driving and ensuring the capitalist engine remains in motion. 
In addition to discussing the historical background of innovation as a subject matter, the management of the same's process likewise calls for appraisal and to this effect, three basic phases are herein explored, namely: (a) concept phase, whereby new ideas are coined, (b) development phase, whereby ideas become projects, and (c) business / marketing phase, whereby projects become new businesses.

Each phase of the innovation process requires different set of managerial and administrative tasks. During the concept phase, the manager's prime task involves the formation of an environment that favours innovation, using a cultural approach. During the development stage, the main task is the creation and definition of proper mechanisms enabling project ideation and development (Chesbrough, 2003; Chesbrough \& Crowther, 2006; Chesbrough \& Vanhaverbeke, 2008). During the business / marketing phase, the suggestion rests on following the classical approach: planning, action and control.

The above division indicates that managing the innovation process is effectively about managing paradoxes. The whole innovation process requires sound management of each individual stage which in turn, often clash with one another. . The manner whereby each company manages innovation processes and the respective paradoxes defines two distinct approaches for the innovation process itself, namely: a closed innovation approach and an open one. (Docherty, 2006; Engeroff \& Balesrin, 2008; Van Der Meer, 2007).

The closed innovation approach demands formal, strict control over the innovation process, most often undertaken by means of employing the Innovation Funnel and the stage gate model (Cooper, 1992; Tidd; Bessant \& Pavitt, 2003). A typical example of this kind of system lies in a funnel of stages applied throughout the innovation process, whereby between stages there are gates designed to filter out potential "losing" projects. At stage-gates, according to Cooper (1992) and Besemer (2000), major successful innovation criteria employed include novelty, feasibility and effectiveness. Funnel inputs comprise ideas, which then become projects and are followed by the transformation of some these into businesses. Success is thus narrowly defined as consisting of a new product, technology, or market for the company (Chesbrough \& Crowther, 2006; Chesbrough \& Vanhaverbeke, 2008). This closed innovation approach essentially focuseson the organization's internal capabilities of the organization, however, only the internal R\&D may effectively elapse through innovation funnel stages (Engeroff \& Balestrino, 2008; Van Der Meer, 2007). 
On the other hand, the open innovation approach rests on the use of either internal or external paths to pursue new technology development. This approach calls for an alternative perspective and can be employed in a number of manners, including collaborative or barter relations such as: relationships with other companies, universities and research institutes, customers, suppliers, importing and exporting ideas and the like (Chesbrough, 2003; Engeroff \& Balestrino, 2008). Major open innovation conventions include: the need to both within and outside the company, work with smart people; an outsourced R\&D, which may bring significant value, and an internal R\&D to which attracts and effectively incorporates the mentioned value. However, for profit generation purposes, research needn't necessarily be developed internally. The ability to build a good business model may prove to be better for the company than pioneering an innovation on the market. Here, gains arise from adopting innovative projects and recommendations include buying and sharing ideas so as to leverage chosen business models (Van Der Meer, 2007; West \& Gallagher, 2008).

Finally, in as much as the conceptualization and management of innovation is concerned, it is worth noting that whether small, medium or large sized, Brazilian companies shall have to increasingly seek not only for innovative products and processes but also pursue the dynamic creation and renewal of innovative solutions, using and sharing ideas within and beyond corporate frontiers, which typically, lie scattered throughout the world. Therefore, the challenge rests on evaluating alternative ways to dynamically manage open and closed innovations.

\subsection{RBV AND DYNAMIC CAPABILITIES}

The resource-based view (RBV) attempts to link competitive advantage sustainability and exploitation with the development of tangible and intangible resources. Pertaining theoretical foundations derive from Barney (1986) , Barney (1991), Barney (1995), Demsetz (1973), Dierickx and Cool (1989), Lippman and Rumelt (1982), Penrose (1959), Peteraf (1993), Prahalad and Hamel (1990), Reed and Defillippi (1990), Rumelt (1984 and 1987), Teece (1980), Teece (1982), Teece (1986), Teece, Pisano and Shuen (1997), Wernerfelt (1984) and others.

RBV in general suggests that in addition to the exploitation of resources and existing external and internal capabilities, sustainable competitive advantage 
calls for the development (investment, renovation and leveraging) of new resources and capabilities (Collis \& Montgomery, 1995; Prahalad \& Hamel, 1990; Teece et al., 1997) or the combination of skills(competence/abilities) and unique resources (essential/dynamic) capable of building, maintaining and enhancing distinctive and hard to imitate advantages. Thus, Resource Based Views pose to link the understanding of competitive advantage and competitive advantage dynamics to resource characteristics, and further comprehend how the latter change over the time (Foss, 1997).

Amongst many alternatives, Barney (1991) defines resources as comprising all the assets, capabilities, organizational processes, firm attributes, information, knowledge, etc. which are controlled by the company and enable the development and setting of strategies to increase efficiency and effectiveness, as duly grouped into three main categories: (1) physical resources such as plants and equipment, (2) human resources including the entire technical team and corporate executives and, (3) organizational resources, namely the set of rules and routines which coordinate corporate human and physical resources. Furthermore, the author pinpoints four mandatory attributes or interrelated conditions so that organizations may maintain sustainable competitive advantages, namely: resources must be valuable, rare amongst current and potential corporate competitors imperfectly imitable, and finally, there cannot be any existing strategically equivalent substitutes for such valuable, yet rare and imperfectly imitable resources.

The RBV theory also emphasizes the relevance of a specific set of capabilities known as "dynamic capabilities", primarily discussed by authors such as Amit and Shoemaker (1993), Dierickx and Cool (1989), Prahalad and Hamel (1990), Sanchez (1996), Teece et al. (1997) amongst others. According to Teece et al. (1997), dynamic capabilities comprise abilities involving the renewal of competencies in full alignment with changing business environments. Capability in turn emphasizes the role of strategic management in adapting, integrating and reconfiguring internal and external organizational skills, resources and functional competencies so as to meet the demands of a given changing environment. To safeguard the comprehension of a corporation's core dynamic capability determining factors, authors introduce three categories, namely:

1. Processes: (1) coordination / integration (static concept) function coordinating both internal and external use of corporate resources, (2) learning function (dynamic concept, focusing on processes whereby trial 
repetition enables improved effective use of resources, (3) reconfiguration function (transformational concept) which focuses on the anticipation of the need for new skills and reconfiguration methods involving resources that enable continued superior performance.

2. Positions: corporate strategic positioning is determined not only by an organization's learning processes, but also by specific assets which establish the company's competitive advantage at a given moment. Assets of the kind typically fall into one or more of the following categories or natures: technological, complementary (trading capacity), financial (cash position and level of leverage), reputational (corporate image and brand), institutional (legislation, public policies, etc.), organizational boundaries (vertical, lateral or horizontal integration) and/or structural. The latter refers to the formal and informal structure of organizations and its external linkages since these pose relevant impact on both the rate and direction of innovation given that skills and capabilities co-evolve.

3. Evolution: the very notion of dependence on pathways suggests that history matters, i.e., a company's previous investments and routine repertoire effectively influences corporate future behavior, whilst organizational experience determines alternatives that managerial levels can easily grasp.

For analytical purposes, Teece (2007) in recent studies broke the concept of Dynamic Capabilities down into several organizational processes or key activities which mobilize corporate resources towards what he names "meta-Dynamic Capacity." This includes human resources, who will effectively be the internal actors. Each collaborator contributes with their individual set of skills and is duly embedded within the organizational structure which in turn portrays it's own history, culture and so forth. Dynamic capabilities are thus a result of the entire mobilization process involving resources and available skills that permeate both the company and its ecosystem.

Meta-Dynamic Capabilities as proposed by Teece (2007) comprise:

1. Mapping of market and technological opportunities: System analysis so as to identify, filter, calibrate and learn from opportunities.

1.1 Key elements: internal processes guiding new technology research, development and selection; processes that prospect innovative suppliers and synergies; processes that optimize the usage of external scientific and technological developments and finally, processes that identify target market segments, changes in customer requirements and innovations. 
2. Exploitation of market and technological opportunities: Structures, processes, models and incentives to seize opportunities.

2.1 Key elements: customer and business model solution scoping; including technology and product architecture selection; architecture design methods; target customer selection;, value capturing mechanism design; decision making protocol selection (comprising the identification of turning points and synergies); enterprise boundary selection so as to manage and control complementary platforms (comprising asset specificity calibration, bottleneck asset control and ownership, management and co-specialization assessment and recognition so as to capture economies); loyalty and commitment building which in turn includes the demonstration of leadership, the establishment of effective communication and the recognition of noneconomic factors, values and culture.

3. Threat and change management: Alignment and realignment of continuous tangible and intangible assets.

3.1 Key elements: decentralization and decomposition (addressing the adoption of flexibilty, of open innovation strategies and of development, integration and coordination skills); governance (comprising scope matching, agency problem mitigation and rent dissipation blockage); co-specialization (including the strategic management of asset combination to further value creation); and knowledge management (addressing learning, knowledge transfer, outreach and know-how integration and intellectual property protection).

For Helfat et al. (2007) the concept of dynamic power refers to an organization's ability to create, expand or modify, specifically, its own resource base. Corporate resource bases include tangible and intangible resources, human capital and organizational capabilities in controlling and accessing the same. This author understands that dynamic capabilities depend on corporate internal and external contexts and therefore performance measures best suit technical abilities and evolutionary fitness.

A given company's ability to create, expand or modify its own resource base must be aligned with the evolutionary interest survive, grow and prosper on the marketplace. Therefore, the level of evolutionary fitness depends on how well corporate dynamic capabilities correspond to the context in which the organization operates. This line of though suggests that major evolutionary fitness dimensions involving the dynamic capability concept include survival, 
growth, value creation, sustainable competitive advantage and profitability (Helfat et al., 2007).

Technical abilities provide an internal performance measure of dynamic capabilities that focuses on raising quality per unit cost. Thus, technical capabilities present two major dimensions. The first comprises the extent of quality of a given action, irrespective of development and capacity utilization costs whilst the second dimension addresses the cost of the ability to create (or purchase) and use technical capabilities (Helfat et al., 2007).

In addition to discussing performance criteria, the context also calls for the understanding of how new dynamic capabilities may be built or acquired. . Building essentially involves dynamic capacity management processes that comprise deliberate "search and selection" (decision making) and "configuration and development (implementing) the organizational resource base. Acquisition in turn requires the ability to relate to that which is acquired and perceived as a type of dynamic capability that prioritizes purposeful and shared creation, expansion and modification of resource bases both within the organization and at partnering institutions.

However, relational capacities only generate benefits for those involved if (1) specific assets are created for the partnership, (2) mutual access to complementary resources is enabled, (3) there is a substantial flow of exchange between partners in compliance with an established set of routines and (4) governance is effective and capable of limiting transaction costs between the firms involved in the effort (Helfat et al., 2007).

Finally, it is worth noting that much like one already perceives nowadays, resources - particularly those pertaining to knowledge, innovation, technology and management - will continue to be the prime source of future competitive elements as long as the required conditions for their operation and renewal remain safeguarded. In other words, resource and capacity development is essentially a challenging task that calls for a deliberate corporate effort in terms of permanent revitalization and continuous learning.

\section{METHODOLOGY}

A triangular, sequential research was conducted given that (1) a qualitative approach, with interviews and content analysis and (2) a quantitative approach, using the gathering, bivariate and multivariate statistical method, were both employed. 
According to Velde et al. (2004) search strategies based on the sequential use of qualitative and quantitative approaches are particularly suitable to validate and enhance interpretation accuracy, enabling broader and deeper comprehension of the reality undergoing investigation. This methodology is likewise recommended for the purpose of creating and subsequently validating a theory or model.

Creswell (2007) states that research resorts to mixed methods in response to the need to collect and analyze both quantitative and qualitative data within a single study. Developments of the kind usually occur during the initial phase of qualitative data collection and analysis, followed by the collection and analysis of quantitative data. During the last phase of interpretation, results are integrated and compared culminating in the study's conclusions. In addition to the exploratory phenomenon itself, this procedure proves to be particularly advantage ouswhen the researcher is building a new research tool.Morse (2003) suggests that this method best suits theory test elements that emerge from the qualitative phase and may also be used to generalize results pertaining to different qualitative samples.

Furthermore, this research was also descriptive in nature. Gil (2002) states that this technique suits surveys that pose to provide a description of the characteristics of a given population or phenomenon or typify relationships between variables.

This research employed the survey method. According to Creswell (2007), surveys seek to determine the incidence and distribution of a population's characteristics and opinions. As of a small, presumably representative sample of such populations, characteristics and opinions are obtained and studied. The surveyed population was represented by industrial companies cataloged at the "GazetaMercantil" database, which employ at least 100 and no more than 5,000 collaborators, selected from a total of 1414 companies. The study then selected from this target population, economic sectors that presented the highest concentration of companies that also fit into IBGE's CNAE fiscal 1.1 classification. A total of 20 sectors were identified and within each 25 enterprises were selected at random. To address the specific scope and objectives of the research, sampling adjustments were made to this strata ${ }^{1}$ including deeming valid only responding companies that at least employeed100 people yet no more than 499 collaborators. Therefore, research comprises surveys conducted at 50 
midsized companies, scattered throughout 12 different economic sectors (Graph 1).

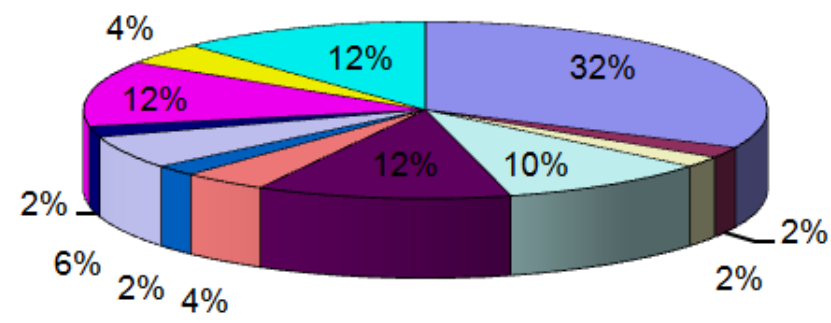

口15- Food and Beverage Product Manufacturing

口17 - Textile Manufacturing

口18 - Clothing Industries

口20 - Timber Products

-22- Printing and Editing

口24 - Chemical Products

口25 - Rubber and Plastic Products

口26 - Non-metallic Mineral Products

-28 - Metallic Products

प29- Machinery and Equipment

口34 - Car Assembly

口36 - Furniture and Other Industries

\section{Graph 1: Dispersion of Valid Respondent Companies and economic sector}

Source: Prepared by the authors.

Is study employed primary and secondary data. Primary data was collected by means of semi-structured interviews conducted with managers and directors, either over the phone or via Skype (Graph 2). Secondary data was collected from GazetaMercantil and IBGE's proceedings, journals and databases. Bloom and Van Reenen's (2007) studies concerning the adoption of managerial practices at foreign companies ground the construction of the interview script that was employed during the survey. 


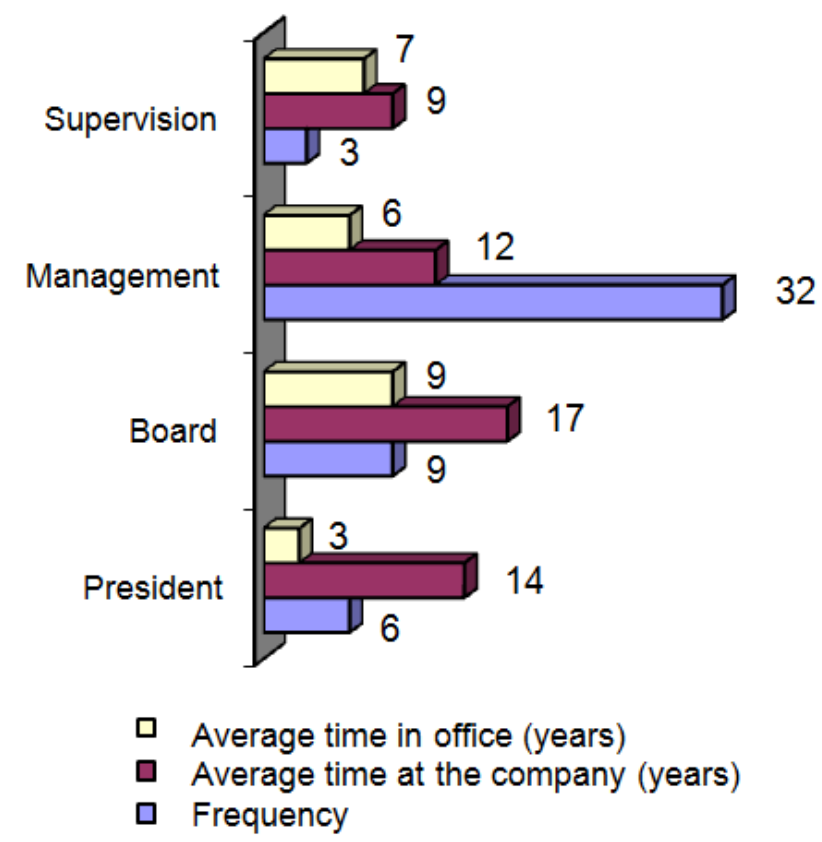

\section{Graph 2: Characterization of respondents.}

Source: Prepared by the authors.

The most relevant advantage of collecting primary data during this study lay in the fact that the interviewer examined interviewee responses (content analysis) and subsequently defined the corporate score for each type of organizational resource. To this effect, a 5-point scale was employed whereby 1 represented the highest incipient level of application/presence of organizational resources, 3 corresponded to an intermediate level and 5 to the highest. In addition to employing an intensive training methodology, interviewers counted on a reference which defined and provided examples of what were deemed typical incipient, intermediate and advanced levels, for every single organization subject to assessment. Thus, when scoring, interpretation biases were minimized. It is worth noting that at each company, only one single interview was conducted, most were recorded and respondents indicated points worth highlighting on the data compiler assumptions for every single reply provided. Once content was analysed, Spearman's correlation coefficient was calculated and variance and cluster analysis conducted (Hair, Anderson, Tatham\& Black, 2005). To this effect, SPSS (Statistical Package for Social Sciences) version 17.0software was employed.

Variance analysis (ANOVA) is based on partitioning the total variance of a given response (dependent variable) into two parts: the first according to the regression model (that is, between groups) and the second deriving from residues or error switch in groups. The higher the first positions above second, 
the more evidence of difference between group averages has been encountered. This model assumes that resulting waste presents a 0 average and constant variance normal distribution (Montgomery, 2000).

The model is set as follows: $y_{i j}=\eta+\beta_{j}+\varepsilon_{i j},=1,2, \ldots, n_{j}, j=1,2,3$

Where by $y_{i j}$ represents each observation of the dependent variable ; $\eta$ a constant (intercept); $\beta_{j}$ the group effect; $j ; \varepsilon_{i j}$ the error associated with the model, and $n_{j}$ the number of observations in group $j$.

Orthogonal contrasts were used to compare the effects of each group (average comparison). Each orthogonal contrast is a linear combination of groups conducted so as to compare effects, on a two by two basis. The hypothesis that the average difference between the groups is equal to zero is tested at a set significance level based on Student's T distribution.

\section{It is worth noting that Spearman's correlation coefficient, commonly known as $\rho$, only considers values within the -1 and 1 range (Pagano \&Gauvreau, 2004), whereby:}

- $\rho=1$, indicates there is a perfect positive correlation between two variables;

- $\rho=-1$, indicates there is a perfect negative correlation between two variables;

- $\rho=0$, means that both variables are not linearly dependent on one another.

Finally, cluster analysis ground on the hierarchical method (Härdle\&Simar, 2007), which emphasizes the assignment of a data set into subsets, known as clusters. Based on the distance between variables V1 to V12findings, the groups formed (clusters) contain similar observations as far as some characteristics (variables) are concerned.

\section{RESULTS AND DISCUSSIONS}

\subsection{PROPOSITION OF GENERAL INNOVATION STAGES}

Three innovation stages are introduced, namely: embryonic, intermediate and mature. Varied innovation concepts and processes such as (1) company innovation versus innovation between and for companies (Peteraf, 1993;Pisano, 2000), (2) linear process versus dynamic process (Barney, 1986; Barney, 1991; Barney, 1995; Bell \& Pavitt, 1993; Berkhout, Hartmann, Duin \& Ortt, 2006), (3) homogeneous actions versus entrepreneurial actions (Chesbrough, 2003; Docherty, 2006; Dosi, 1982; Eisenhardt \& Martin, 2000; Engeroff \& Balestrino, 
2008; Etzkowitz, 2004), (4) closed innovation versus open innovation (Freeman, 1994; Freeman, 1995; Gava, 2007; Kline \& Rosenberg, 1986; Leydesdorff \& Meyer, 2006; Leydesdorff, Dolfsma \& Panne, 2006) and (5) resource stock as a competitive advantage versus dynamic capabilities to innovate and learn safeguarding business sustainability, were employes in an adaptive manner (Lundvall, 1992; Nelson \& Winter, 1977; Penrose, 1959; Prahalad \& Hamel, 1990; Teece et al., 1997; Teece, 2007; Teece \& Pisano, 1994; Van der meer, 2007; Winter, 1988).

During the embryonic stage, vital innovation strategies include conducting technological benchmarking and monitoring market trends. At this stage, the innovation process itself is typically linear and non-systematic, whereby existing knowledge and technology that is readily available on the marketplace, is either replicated and/or internally adapted to address technical problems or respond to external pressure. Timely product and process innovations are thus generated. (Figure 1).

\section{Figure 1: Overall Innovation Framework and the Embryonic Stage.}

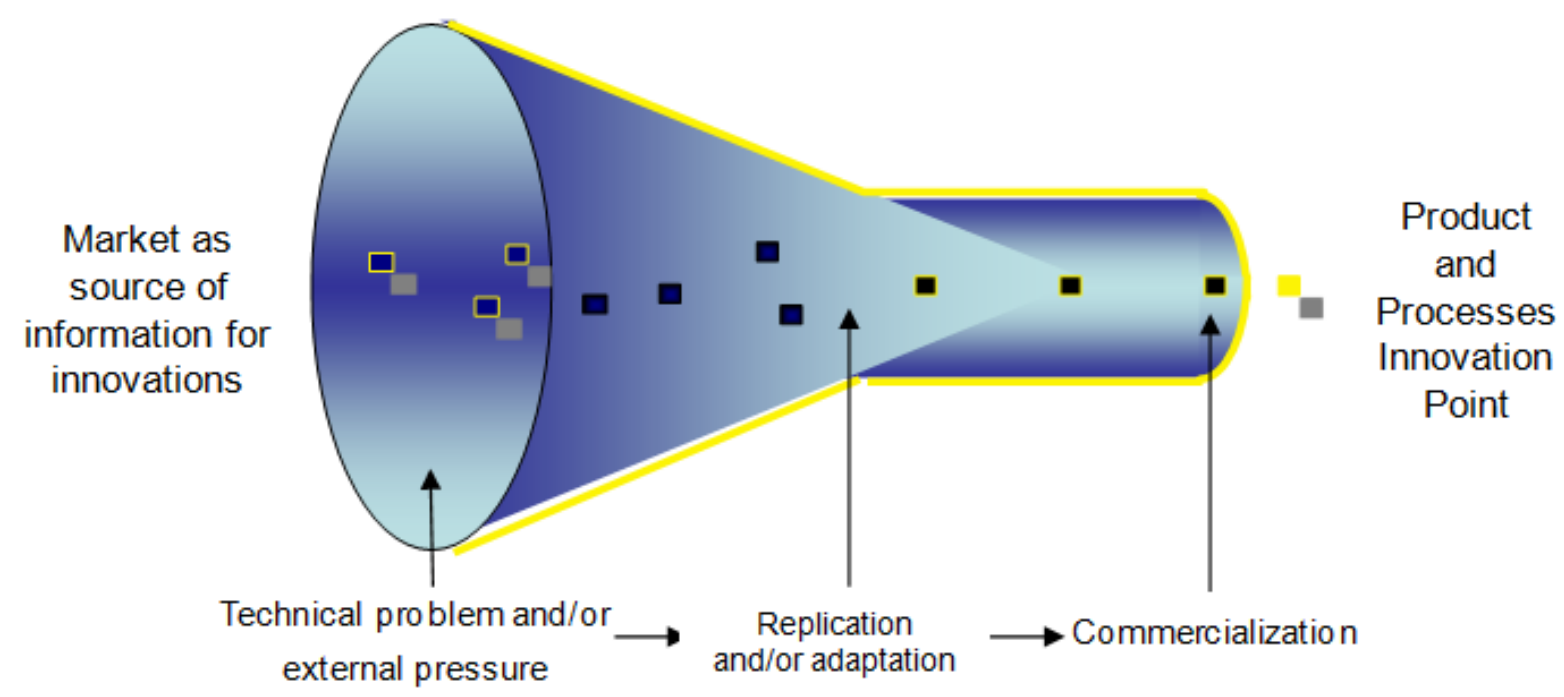

Source: Chesbrough (2003).

During the intermediate stage, the prevailing innovation strategy is that of product and process technological and development differentiation. At this stage, the innovation process is typically mixed and closed in nature. The process follows a logical sequence which is not necessarily continuous, whereby innovation-inducing information increases as market, science and technology are monitored, and both concept development and marketing phases flow in a 
dynamic manner given the extent of contact that takes place between business areas that interact along the innovation process. This results in product and process innovations and in organizational innovations (Figure 2).

Figure 2: Overall Innovation Framework and the Intermediate Stage.

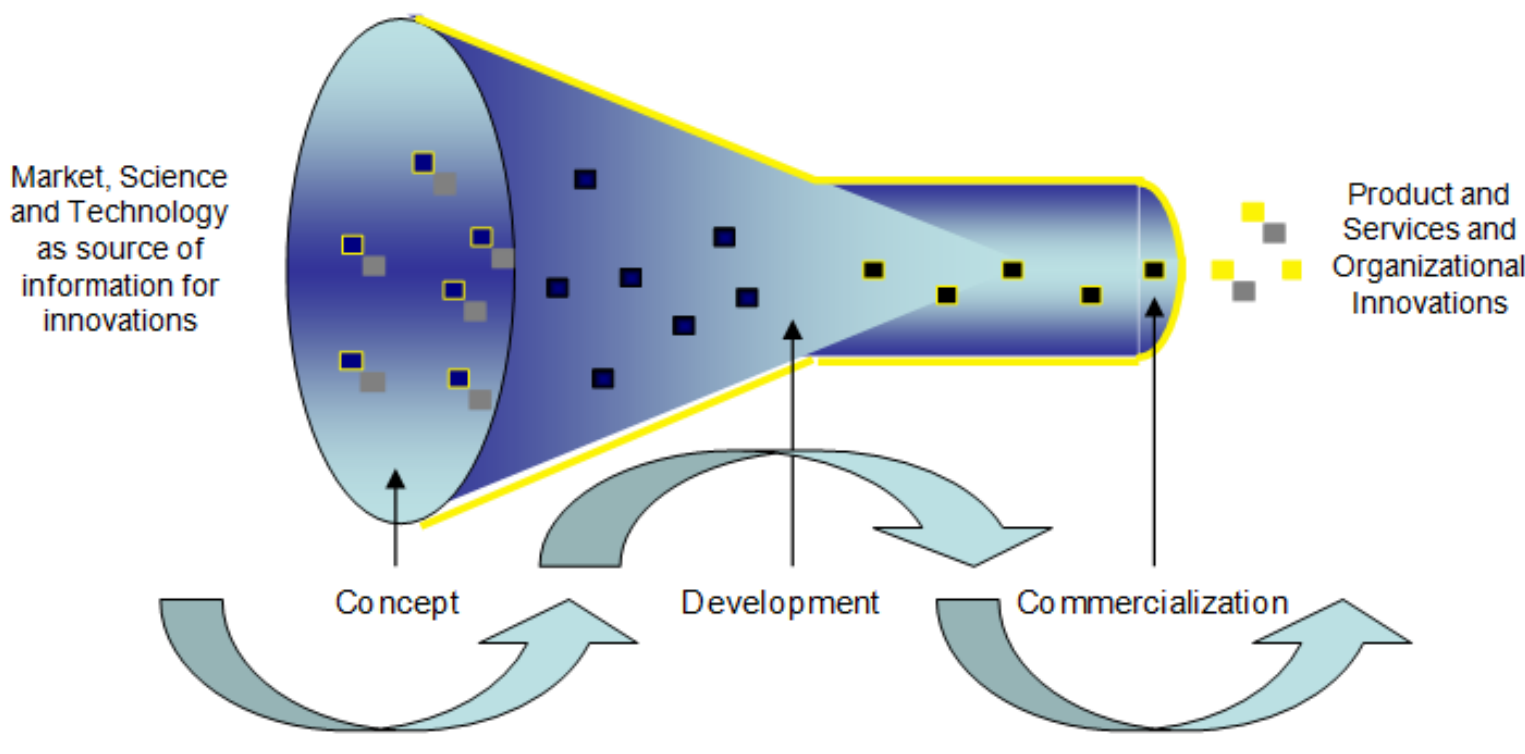

Source: Chesbrough (2003).

During the stage of maturity, mandatory innovation strategies involve seeking technological leadership, systematically developing innovative solutions (such as new or upgraded products and processes and new organizational practices) plus, and giving rise to new businesses. The innovation process is characterized as being interactive and open, i.e., dynamic interactions occur within companies, amongst individual companies and with science and technology institutions (STI). Financial institutions and the government (FIG) also provide legal and capital support and the very mentioning of the current state of science, technology and market permeate all innovation phases, from concept and development to commercialization (Figure 3). 
Figure 3: Overall Innovation Framework and the Mature Stage.

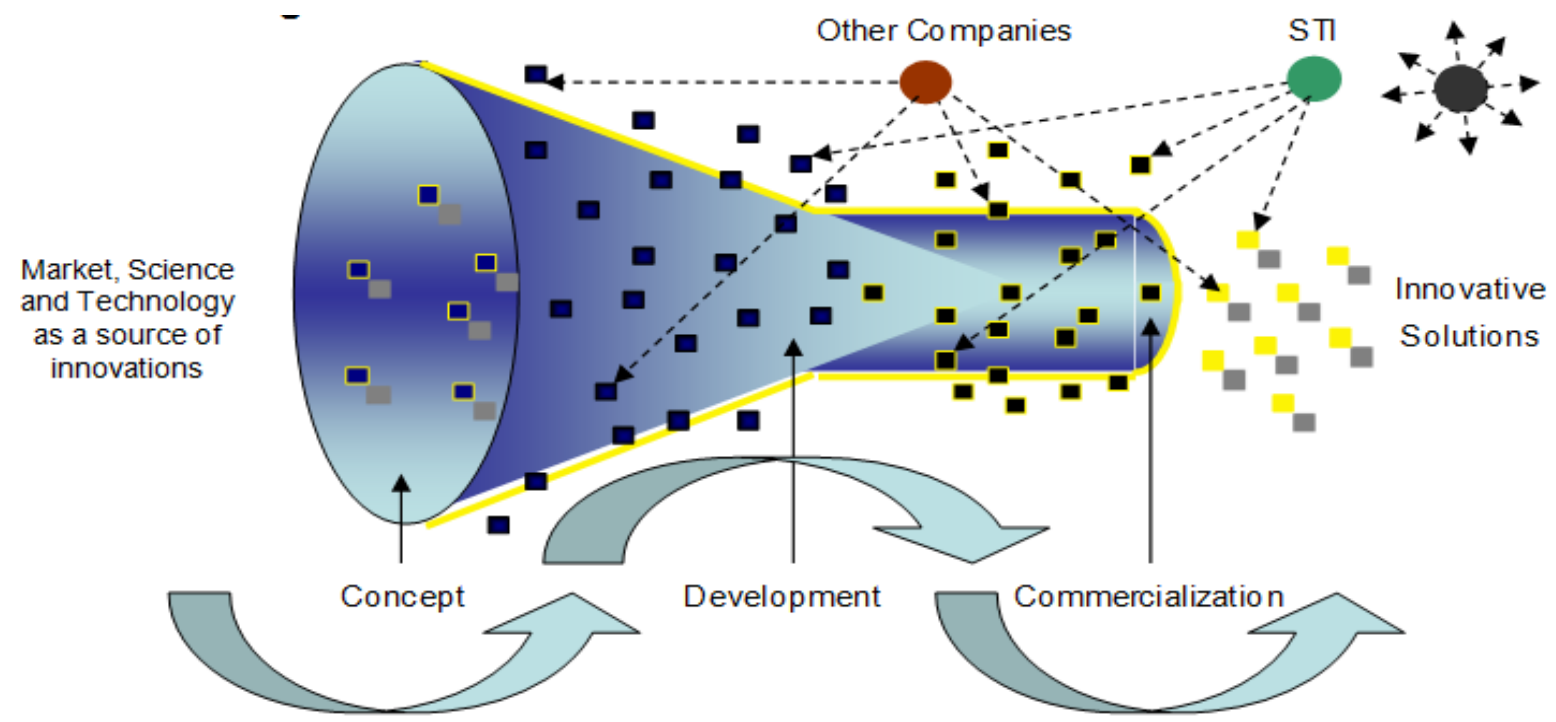

Source: Chesbrough (2003).

Other than the above mentioned embryonic, intermediate, and mature stages, there are numerous innovation strategy and action alternatives which are likewise taken into account and adopted by midsized businesses. Therefore, the intent herein does not include suggesting optimal conditions for innovation at midsized companies whenever possible and feasible, but rather, to offer indicatives that may characterize the current state of innovation at these companies and simultaneously suggest alternative pathways which may shape future, sturdier stages in terms of innovation.

Another point of relevance pertains to the fact that many midsized companies should not necessarily readily incorporate - whether in all or in part the precepts laid forth concerning typical mature stages since those of the intermediate stage, or even the embryonic one might prove to be more than adequate before their momentary needs. The challenge therefore rests on characterizing the current state of innovation, and subsequently dynamically adjusting to future changes in the external and internal environment. This may only demand occasional or extensive search for sturdier innovation stages.

\subsection{CHARACTERIZATION OF INNOVATION STAGES AT BRAZILIAN MIDSIZED} COMPANIES

The fifty studied companies are scattered throughout twelve different economic sectors whereby: $32 \%$ operate in the manufacturing of food and 
beverages products $72 \%$ are located in the South and Southeast of Brazil, $88 \%$ are privately held and on average employ 244 collaborators. On average these companies face 28 direct competitors, 38\% were founded in the 70's and 80's and are usually lead by four directors. Typically they employ an average of only one single woman in managerial positions and in most cases, only have one production unit. Employing on average two family members, 54\% are family businesses lead by a family member CEO who in $85 \%$ of the cases arose from the family's second generation (43\%).

Application of innovation stage precepts (see item 4.1) resulted in the following findings: in terms of product and process innovation, most companies $(42 \%)$ are currently experiencing the intermediate stage (score 3 ); from an organizational innovation stand point, the embryonic stage (score 1 and 2) concentrates the highest (64\%) number of companies whilst, if one considers both types of innovation, $38 \%$ of companies are in the embryonic stage.

In as much as the mature stage (score 4 and 5 ) is concerned, product and process innovation presented the highest concentrations (20\%).

Nevertheless, its worth noting that quite a few companies present hybrid situations, i.e. they are undergoing distinct stages in terms of both product and process innovation and organizational innovation (Graph 3).

\section{Graph 3: Percentual Distribution of Innovation Stages at Midsized Companies}

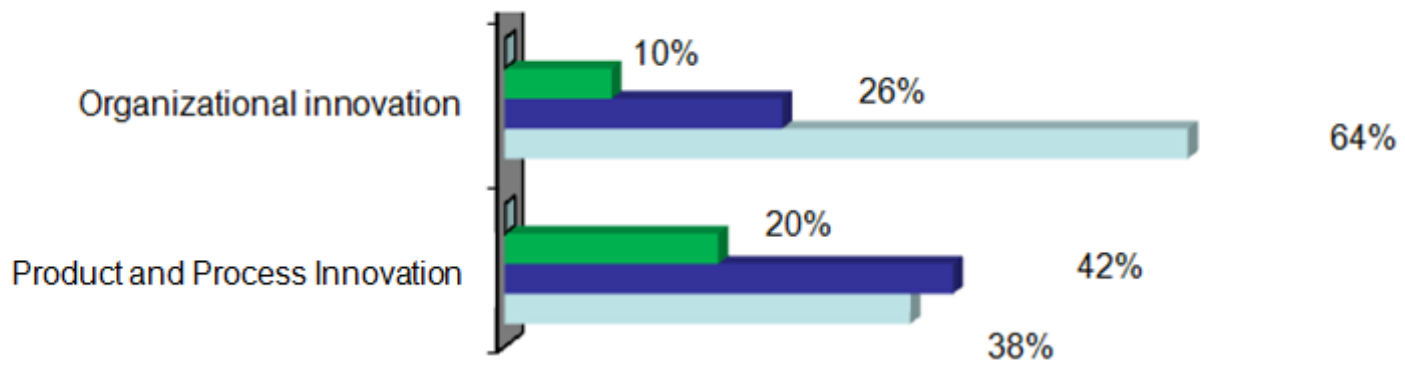

$\square$ Advanced Stage $\quad$ Intermediate Stage $\quad$ Embryonic Stage

Source: Prepared by the authors.

When analyzing the stages of innovation from an organizational aspect perspective (net operating income, audit hiring, whether there is a board of supervisors and of directors, and the presence of export activities) it soon becomes apparent that these tend to play increasingly relevant roles during the mature stage. This holds true for both product and process innovation and to organizational 
innovation. Furthermore, one notices the existence of an upward movement, i.e. as stages evolve, there is a greater number of companies that export, hire audits and which are lead by supervisory and administrative boards (Table 1 ).

Table 1: Innovation Stages and Organizational Aspects.

\begin{tabular}{|c|c|c|c|c|c|}
\hline Stage & $\begin{array}{c}\text { Average Net } \\
\text { Operational } \\
\text { Income }(\mathbf{R} \$)\end{array}$ & $\begin{array}{l}\text { Audito } \\
\text { r } \\
\text { Hiring }\end{array}$ & $\begin{array}{c}\text { Existence of } \\
\text { an } \\
\text { Administrativ } \\
\text { e } \\
\text { Council/Board }\end{array}$ & $\begin{array}{c}\text { Existence } \\
\text { of an } \\
\text { Audit } \\
\text { Committe } \\
\text { e }\end{array}$ & $\begin{array}{l}\text { Exportin } \\
\text { g } \\
\text { Company }\end{array}$ \\
\hline \multicolumn{6}{|c|}{ Products and Process Innovation } \\
\hline $\begin{array}{l}\text { Embryonic } \\
\text { Stage }\end{array}$ & $16.379 .603,69$ & $42 \%$ & $53 \%$ & $37 \%$ & $63 \%$ \\
\hline $\begin{array}{l}\text { Intermediat } \\
\text { e Stage }\end{array}$ & $27.668 .352,56$ & $67 \%$ & $48 \%$ & $33 \%$ & $48 \%$ \\
\hline $\begin{array}{l}\text { Mature } \\
\text { Stage }\end{array}$ & $\begin{array}{c}23.271 .187,15 \\
5\end{array}$ & $90 \%$ & $60 \%$ & $60 \%$ & $80 \%$ \\
\hline \multicolumn{6}{|c|}{ Organizational Innovation } \\
\hline $\begin{array}{l}\text { Embryonic } \\
\text { Stage }\end{array}$ & $16.050 .949,23$ & $53 \%$ & $50 \%$ & $34 \%$ & $53 \%$ \\
\hline $\begin{array}{l}\text { Intermediat } \\
\text { e Stage }\end{array}$ & $34.787 .844,69$ & $77 \%$ & $46 \%$ & $46 \%$ & $62 \%$ \\
\hline $\begin{array}{l}\text { Mature } \\
\text { Stage }\end{array}$ & $19.617 .477,78$ & $80 \%$ & $80 \%$ & $60 \%$ & $100 \%$ \\
\hline
\end{tabular}

Source: Prepared by the authors.

\subsection{ORGANIZATIONAL RESOURCES ATMIDSIZEDBRAZILIAN COMPANIES}

This study's core hypothesis may be summarized as follows: $H_{0}=$ organizational resources do not impact innovation stages at local midsized companies. To test this hypothesis the following procedures were conducted: (a) calculation of the correlation between identified variables (b) calculation of the difference between embryonic, intermediate and mature stage averages for both product and process innovation and organizational innovation, and (c) cluster mapping, whereby three were identified.

The variables employed were product and process innovation (PPI), organizational innovation (OI), modern production technique adoption (v1), 
production process improvement (v2); production performance monitoring (v3); promotion of superior performance professionals(v4); human capital attraction (v5); human capital retention (v6), customer orientation (v7); stakeholder relationships(v8); social and environmental sustainability (v9) strategic planning ( v10); financial management practices (v11); and organizational levels (v12).

Variables $v 1$ to $\mathrm{v} 12$ seem to mostly refer to organizational resources, whilst PPI and OI refer to two types of innovation that are adopted at workplaces.

For starters, p-value calculations revealed the existence of significant associations between innovations, both within products and process innovations and those of organizational nature. Furthermore, except for variable v12, analyzed organizational resources, indicate that both types of innovation are not associated with the range of hierarchical levels at midsized companies.

Likewise, the association between talent progress (v4) and organizational innovation was not significant. Much like findings deriving from Spearman's correlation coefficient, here too associations were found to be more intense (between 0.4 and 0.6) for both types of innovation (PPI and OI) involving organizational resources devoted to production ( $11, \mathrm{v} 2$ and $\mathrm{v} 3$ ), strategy ( $\mathrm{v} 7$ and v10) and finance (v11) (Tables 2 and 3).

Table 2: Spearman's correlation coefficient followed by $p$-value and between PPI and other variables.

\begin{tabular}{cccccc}
\hline $\mathbf{v 1}$ & 0,461 & $\mathbf{v 5}$ & 0,344 & $\mathbf{v 9}$ & 0,267 \\
& 0,001 & & 0,014 & & 0,061 \\
\hline $\mathbf{v 2}$ & 0,642 & $\mathbf{v 6}$ & 0,254 & $\mathbf{v 1 0}$ & 0,567 \\
& $<0,001$ & & 0,075 & & $<0,001$ \\
\hline $\mathbf{v 3}$ & 0,586 & $\mathbf{v 7}$ & 0,409 & $\mathbf{v 1 1}$ & 0,676 \\
& $<0,001$ & & 0,003 & & $<0,001$ \\
\hline $\mathbf{v 4}$ & 0,317 & $\mathbf{v 8}$ & 0,280 & $\mathbf{v 1 2}$ & 0,123 \\
& 0,025 & & 0,049 & & 0,396 \\
\hline
\end{tabular}

Level of significance: $*=1 \% ; * *=5 \% ; * * *=10 \%$; NS = not significant Source: Prepared by the authors. 
Table 3: Spearman's correlation coefficient followed by p-value and between $\mathrm{OI}$ and other variables.

\begin{tabular}{rrrrrr}
\hline $\mathbf{v 1}$ & 0,583 & $\mathbf{v 5}$ & 0,309 & $\mathbf{v 9}$ & 0,444 \\
& $<0,001$ & & 0,029 & & 0,001 \\
\hline $\mathbf{v 2}$ & 0,441 & $\mathbf{v 6}$ & 0,376 & $\mathbf{v 1 0}$ & 0,541 \\
& 0,001 & & 0,007 & & $<0,001$ \\
\hline $\mathbf{v 3}$ & 0,516 & $\mathbf{v 7}$ & 0,519 & $\mathbf{v 1 1}$ & 0,463 \\
& $<0,001$ & & $<0,001$ & & 0,001 \\
\hline $\mathbf{v 4}$ & 0,201 & $\mathbf{v 8}$ & 0,423 & $\mathbf{v 1 2}$ & 0,126 \\
& 0,162 & & 0,002 & & 0,383 \\
\hline
\end{tabular}

Level of significance: $*=1 \% ; * *=5 \% ; * * *=10 \%$; NS = not significant Source: Prepared by the authors.

Analysis of the difference between representative group averages undergoing embryonic (G1), intermediate (G2) and mature (g3) stages revealed that production performance monitoring of (v3), strategic planning (v10) and financial management ( $v 11$ ) effectively comprise the set of organizational resources that different at studied midsized companies in as much as their respective stages of products and processes (PPI) and organizational (OI) innovation is concerned. It is worth noting that the number of organizational levels does not differentiate the analyzed groups (g1, g2 and g3) when considering both types of innovation (PPI and OI) (Tables 4 and 5).

In terms of products and processes innovation (PPI) specifically, production process improvement (v2) differentiated groups subject to analysis. Adoption of modern production techniques ( $v 1$ ) and attraction of human capital (v5) only didn 't differentiate the intermediate group (G2) from the mature group (G3). Furthermore, human capital retention (v6) and social and environmental sustainability (v9) did not differentiate the embryonic group (g1) from the intermediate group (g2). The promotion of professional performance (v4), customer orientation ( $v 7$ ) and stakeholder relations (v8), only differentiated the embryonic group (g1) from the mature group (G3) (Tables 4 and 5).

In terms of organizational innovation (OI) the adoption of modern production techniques (v1), production improvement processes (v2), human capital attraction (v5), human capital retention (v6), customer orientation (v7) and social and environmental sustainability (v9), only didn't differentiate the intermediate group 
(g2) from the mature group (G3). The promotion of professionals presenting superior performance (v4) and stakeholder relations (v8), only differentiated the embryonic group (g1) from the intermediate group (g2) (Tables 4 and 5).

Table 4: Comparison between the PPI groups and other variables v1 - v12.

\begin{tabular}{|c|c|c|c|c|c|}
\hline \multirow[t]{2}{*}{ Variable } & \multirow{2}{*}{$\frac{\text { Comparison }}{\mathrm{g} 1-\mathrm{g} 2}$} & \multirow{2}{*}{$\begin{array}{c}\text { Difference } \\
-0,850\end{array}$} & \multirow{2}{*}{$\frac{p \text {-value }}{0,018}$} & \multicolumn{2}{|c|}{ CI $95 \%$} \\
\hline & & & & $-1,549$ & $-0,150$ \\
\hline \multirow[t]{3}{*}{ v1 } & $\mathrm{g} 1-\mathrm{g} 3$ & $-1,321$ & 0,004 & $-2,184$ & $-0,458$ \\
\hline & g2 - g3 & $-0,471$ & 0,270 & $-1,320$ & 0,377 \\
\hline & $\mathrm{g} 1$ - g2 & $-0,930$ & 0,001 & $-1,445$ & $-0,415$ \\
\hline \multirow[t]{3}{*}{$\mathrm{v} 2$} & g1 - g3 & $-1,663$ & $<, 0001$ & $-2,299$ & $-1,027$ \\
\hline & g2 - g3 & $-0,733$ & 0,023 & $-1,359$ & $-0,108$ \\
\hline & $\mathrm{g} 1-\mathrm{g} 2$ & $-0,872$ & 0,009 & $-1,511$ & $-0,233$ \\
\hline \multirow[t]{3}{*}{ v3 } & $\mathrm{g} 1-\mathrm{g} 3$ & $-1,658$ & 0,000 & $-2,446$ & $-0,869$ \\
\hline & $\mathrm{g} 2-\mathrm{g} 3$ & $-0,786$ & 0,047 & $-1,561$ & $-0,010$ \\
\hline & $\mathrm{g} 1$ - g2 & $-0,276$ & 0,377 & $-0,897$ & 0,346 \\
\hline \multirow[t]{3}{*}{ v4 } & $\mathrm{g} 1-\mathrm{g} 3$ & $-0,895$ & 0,023 & $-1,662$ & $-0,128$ \\
\hline & g2 - g3 & $-0,619$ & 0,105 & $-1,373$ & 0,135 \\
\hline & $\mathrm{g} 1$ - g2 & $-0,589$ & 0,015 & $-1,058$ & $-0,120$ \\
\hline \multirow[t]{3}{*}{ v5 } & $\mathrm{g} 1$ - g3 & $-0,484$ & 0,099 & $-1,063$ & 0,095 \\
\hline & g2 - g3 & 0,105 & 0,713 & $-0,465$ & 0,674 \\
\hline & $\mathrm{g} 1-\mathrm{g} 2$ & 0,005 & 0,989 & $-0,700$ & 0,710 \\
\hline \multirow[t]{3}{*}{ v6 } & g1 - g3 & $-0,747$ & 0,090 & $-1,617$ & 0,122 \\
\hline & $\mathrm{g} 2-\mathrm{g} 3$ & $-0,752$ & 0,083 & $-1,607$ & 0,103 \\
\hline & $\mathrm{g} 1-\mathrm{g} 2$ & $-0,446$ & 0,162 & $-1,078$ & 0,186 \\
\hline \multirow[t]{3}{*}{ v7 } & g1 - g3 & $-1,084$ & 0,008 & $-1,864$ & $-0,304$ \\
\hline & $\mathrm{g} 2-\mathrm{g} 3$ & $-0,638$ & 0,101 & $-1,405$ & 0,129 \\
\hline & $\mathrm{g} 1$ - g2 & $-0,378$ & 0,224 & $-0,996$ & 0,239 \\
\hline \multirow[t]{3}{*}{ v8 } & $\mathrm{g} 1$ - g3 & $-0,674$ & 0,082 & $-1,435$ & 0,088 \\
\hline & $\mathrm{g} 2-\mathrm{g} 3$ & $-0,295$ & 0,432 & $-1,044$ & 0,454 \\
\hline & $\mathrm{g} 1-\mathrm{g} 2$ & $-0,211$ & 0,541 & $-0,898$ & 0,477 \\
\hline \multirow[t]{3}{*}{ v9 } & $\mathrm{g} 1-\mathrm{g} 3$ & $-1,011$ & 0,021 & $-1,859$ & $-0,162$ \\
\hline & $\mathrm{g} 2-\mathrm{g} 3$ & $-0,800$ & 0,060 & $-1,634$ & 0,034 \\
\hline & $\mathrm{g} 1-\mathrm{g} 2$ & $-0,466$ & 0,058 & $-0,949$ & 0,017 \\
\hline \multirow[t]{3}{*}{ v10 } & $\mathrm{g} 1$ - g3 & $-1,595$ & $<, 0001$ & $-2,191$ & $-0,999$ \\
\hline & $\mathrm{g} 2-\mathrm{g} 3$ & $-1,129$ & 0,000 & $-1,715$ & $-0,542$ \\
\hline & $\mathrm{g} 1$ - g2 & $-0,589$ & 0,030 & $-1,117$ & $-0,061$ \\
\hline \multirow[t]{3}{*}{ v11 } & $\mathrm{g} 1-\mathrm{g} 3$ & $-2,084$ & $<, 0001$ & $-2,736$ & $-1,433$ \\
\hline & $\mathrm{g} 2-\mathrm{g} 3$ & $-1,495$ & $<, 0001$ & $-2,136$ & $-0,854$ \\
\hline & $\mathrm{g} 1$ - g2 & $-0,514$ & 0,191 & $-1,293$ & 0,265 \\
\hline \multirow[t]{2}{*}{ v12 } & $\mathrm{g} 1-\mathrm{g} 3$ & $-0,095$ & 0,844 & $-1,056$ & 0,867 \\
\hline & $\mathrm{g} 2-\mathrm{g} 3$ & 0,419 & 0,377 & $-0,527$ & 1,365 \\
\hline
\end{tabular}

Level of significance: $*=1 \% ; * *=5 \% ; * * *=10 \% ;$ NS $=$ not significant 
Source: Prepared by the authors.

Table 5: Comparison between the OI groups and other variables v1 - v12.

\begin{tabular}{|c|c|c|c|c|c|}
\hline Variable & Comparison & Difference & p-value & & CI 95\% \\
\hline \multirow[t]{3}{*}{$\mathbf{v 1}$} & g1 - g2 & $-1,204$ & 0,001 & $-1,877$ & $-0,532$ \\
\hline & $\mathrm{g} 1-\mathrm{g} 3$ & $-1,681$ & 0,001 & $-2,665$ & $-0,698$ \\
\hline & g2 - g3 & $-0,477$ & 0,377 & $-1,553$ & 0,600 \\
\hline \multirow[t]{3}{*}{$\mathrm{v} 2$} & g1 - g2 & $-1,060$ & 0,001 & $-1,658$ & $-0,462$ \\
\hline & $g 1-g 3$ & $-0,906$ & 0,043 & $-1,781$ & $-0,032$ \\
\hline & $\mathrm{g} 2-\mathrm{g} 3$ & 0,154 & 0,748 & $-0,803$ & 1,111 \\
\hline \multirow[t]{3}{*}{ v3 } & $\mathrm{g} 1-\mathrm{g} 2$ & $-1,584$ & $<, 0001$ & $-2,210$ & $-0,958$ \\
\hline & $\mathrm{g} 1-\mathrm{g} 3$ & $-0,969$ & 0,038 & $-1,884$ & $-0,054$ \\
\hline & $\mathrm{g} 2-\mathrm{g} 3$ & 0,615 & 0,223 & $-0,386$ & 1,617 \\
\hline \multirow[t]{3}{*}{$\mathrm{v} 4$} & $\mathrm{~g} 1-\mathrm{g} 2$ & $-0,659$ & 0,048 & $-1,312$ & $-0,006$ \\
\hline & $\mathrm{g} 1-\mathrm{g} 3$ & $-0,413$ & 0,389 & $-1,367$ & 0,542 \\
\hline & g2 - g3 & 0,246 & 0,638 & $-0,799$ & 1,291 \\
\hline \multirow[t]{3}{*}{ v5 } & $\mathrm{g} 1-\mathrm{g} 2$ & $-0,748$ & 0,002 & $-1,215$ & $-0,281$ \\
\hline & $g 1-g 3$ & $-0,594$ & 0,087 & $-1,277$ & 0,089 \\
\hline & g2 - g3 & 0,154 & 0,681 & $-0,593$ & 0,901 \\
\hline \multirow[t]{3}{*}{ v6 } & $\mathrm{g} 1-\mathrm{g} 2$ & $-0,817$ & 0,023 & $-1,515$ & $-0,120$ \\
\hline & $\mathrm{g} 1-\mathrm{g} 3$ & $-1,125$ & 0,031 & $-2,145$ & $-0,105$ \\
\hline & $g 2-g 3$ & $-0,308$ & 0,582 & $-1,424$ & 0,809 \\
\hline \multirow[t]{3}{*}{ v7 } & $\mathrm{g} 1-\mathrm{g} 2$ & $-0,964$ & 0,003 & $-1,583$ & $-0,345$ \\
\hline & $\mathrm{g} 1-\mathrm{g} 3$ & $-1,256$ & 0,008 & $-2,162$ & $-0,351$ \\
\hline & g2 - g3 & $-0,292$ & 0,556 & $-1,283$ & 0,699 \\
\hline \multirow[t]{3}{*}{ v8 } & $\mathrm{g} 1-\mathrm{g} 2$ & $-0,853$ & 0,007 & $-1,463$ & $-0,244$ \\
\hline & $\mathrm{g} 1-\mathrm{g} 3$ & $-0,669$ & 0,138 & $-1,559$ & 0,222 \\
\hline & g2 - g3 & 0,185 & 0,705 & $-0,790$ & 1,159 \\
\hline \multirow[t]{3}{*}{ v9 } & $\mathrm{g} 1-\mathrm{g} 2$ & $-0,974$ & 0,006 & $-1,656$ & $-0,291$ \\
\hline & $\mathrm{g} 1-\mathrm{g} 3$ & $-1,081$ & 0,034 & $-2,079$ & $-0,083$ \\
\hline & g2 - g3 & $-0,108$ & 0,844 & $-1,200$ & 0,985 \\
\hline \multirow[t]{3}{*}{ v10 } & $\mathrm{g} 1-\mathrm{g} 2$ & $-0,966$ & 0,000 & $-1,445$ & $-0,488$ \\
\hline & $\mathrm{g} 1-\mathrm{g} 3$ & $-1,813$ & $<, 0001$ & $-2,512$ & $-1,113$ \\
\hline & g2 - g3 & $-0,846$ & 0,031 & $-1,612$ & $-0,081$ \\
\hline \multirow[t]{3}{*}{ v11 } & $\mathrm{g} 1-\mathrm{g} 2$ & $-1,038$ & 0,001 & $-1,621$ & $-0,456$ \\
\hline & $\mathrm{g} 1-\mathrm{g} 3$ & $-2,100$ & $<, 0001$ & $-2,952$ & $-1,248$ \\
\hline & $\mathrm{g} 2-\mathrm{g} 3$ & $-1,062$ & 0,027 & $-1,994$ & $-0,129$ \\
\hline \multirow[t]{3}{*}{ v12 } & $\mathrm{g} 1-\mathrm{g} 2$ & $-0,166$ & 0,683 & $-0,976$ & 0,645 \\
\hline & $\mathrm{g} 1-\mathrm{g} 3$ & $-0,781$ & 0,191 & $-1,966$ & 0,404 \\
\hline & g2 - g3 & $-0,615$ & 0,345 & $-1,912$ & 0,682 \\
\hline
\end{tabular}

Level of significance: $*=1 \% ; * *=5 \% ; * * *=10 \% ;$ NS $=$ not significant

Source: Prepared by the authors.

As far as the three clusters that were formed are concerned, findings indicate that the types innovation studied herein (PPI and OI) and organizational resources 
pondered ( $\mathrm{v} 1$ to $\mathrm{v} 12$ ) tend to be more expressive in the third cluster. Furthermore, an upward trend in as much as averages are concerned, was also identified as of the first towards the third cluster, except for a handful of features such as attraction of human capital (v5), stakeholder relations and social and environmental sustainability (v9) (Table 6 and Graph 4).

Table 6: Variable averages in the 3 groups formed.

\begin{tabular}{|c|c|c|c|c|c|c|c|c|c|c|c|c|c|c|c|}
\hline Groups & $\mathbf{n}$ & PPI & OI & V1 & V2 & V3 & V4 & V5 & V6 & V7 & vs & V9 & V10 & V11 & V12 \\
\hline 1 & 36 & 2,22 & 1,64 & 1,81 & 2,03 & 2,08 & 2,22 & 2,53 & 2,03 & 2,33 & 1,44 & 1,72 & 1,22 & 1,61 & 4,39 \\
\hline 2 & 5 & 4,20 & 3,80 & 4,20 & 3,80 & 4,00 & 3,00 & 3,00 & 2,80 & 3,80 & 2,20 & 2,80 & 3,40 & 4,00 & 6,00 \\
\hline 3 & 9 & 3,33 & 2,67 & 2,67 & 3,44 & 3,56 & 2,78 & 3,00 & 2,56 & 3,67 & 3,11 & 3,11 & 2,22 & 2,33 & 3,22 \\
\hline
\end{tabular}

Source: Prepared by the authors.

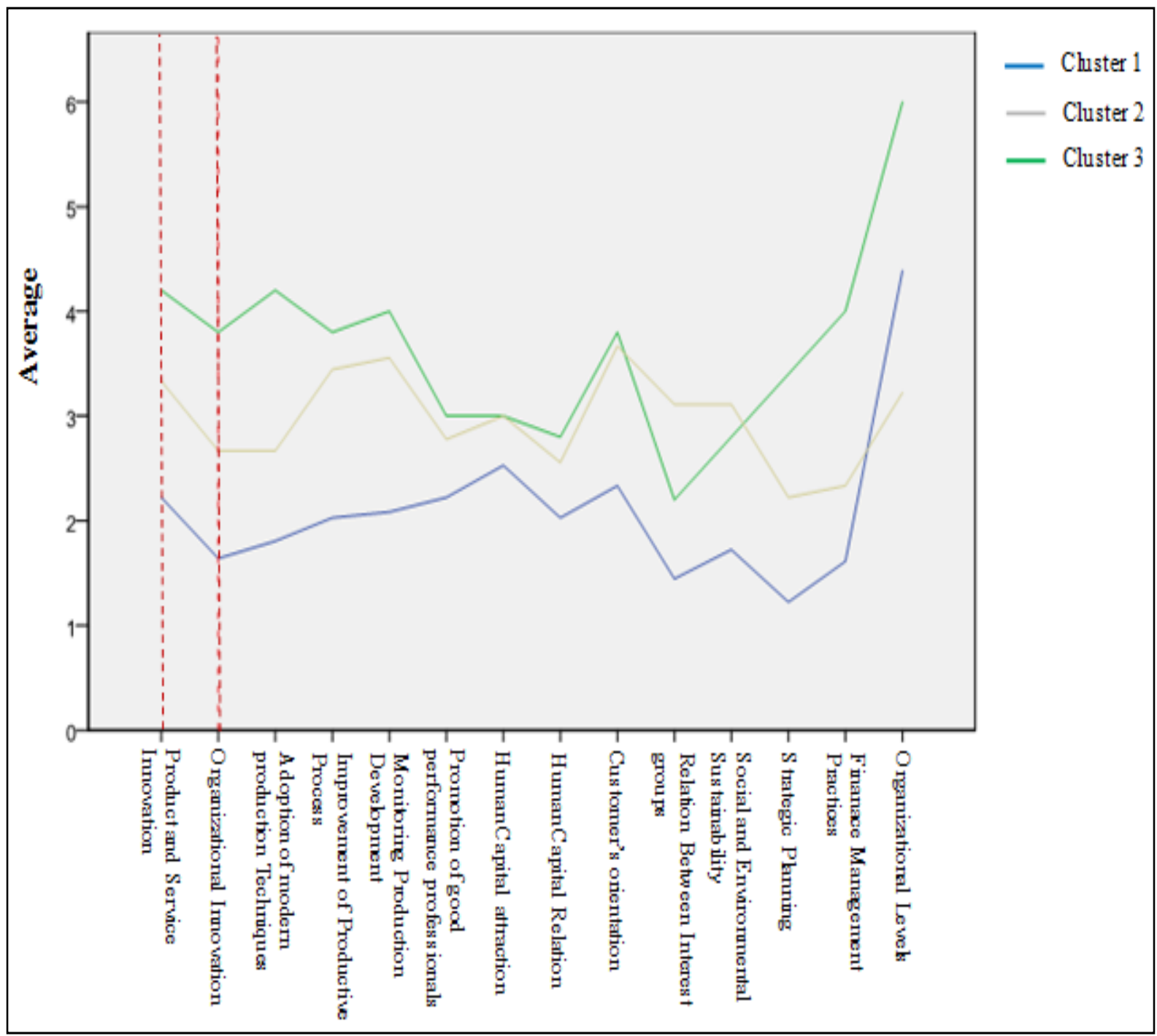

Graph 4:Variable averages in the 3 clusters formed.

Source: Prepared by the authors. 
Findings also revealed that the number of companies decreased from the first to the third cluster and that innovation in products and processes is more significant in the three clusters formed when compared to organizational innovation. If one establishes an association between clusters formed and the proposed innovation stages, observations indicate that the first cluster is representative of the embryonic stage, the second of the intermediate stage, and the third of the mature stage. Thus, one may infer that the embryonic cluster has the largest number of midsized companies whilst the mature cluster greater sturdiness both in terms of innovation and of organizational resources. Finally, given results obtained when calculating correlations, both ANOVA and clusters must be rejected by the HOconclude, i.e., organizational resources do impact innovation stages at midsized businesses.

\section{FINAL CONSIDERATIONS}

Innovative profiles of studied midsized companies are characterized by the intermediate stage in terms of products and processes innovation and by the embryonic stage in as much as organizational innovation is concerned. This usually indicates that for product and process innovation, the prevailing strategy involves technological differentiation and the development of products and processes whilst the innovation process itself is of a mixed and closed nature. In as much as organizational innovation is concerned the most important strategy comprises conducting technological benchmarking and monitoring market trends, whilst the innovation process in itself is of a linear and non-systematic kind.

It is worth noting that despite the fact that embryonic and intermediate stages do concentrate most midsized companies, mature stages present greater sturdiness in terms of innovation and organizational resources. This evidences the fact that organizational resources do effectively impact innovation stages at local midsized companies, particularly in as much as some features are concerned, namely: modern production technique adoption ( $\mathrm{v} 1)$, production process improvement ( $\mathrm{v} 2)$; production performance monitoring ( $\mathrm{v} 3$ ), customer orientation ( $\mathrm{v} 7$ ) strategic planning (v10) and financial management practices (v11). It also seems clear that in general, companies experiencing the mature stage present higher value in comparison to those at the intermediate level. In turn, the latter prevail over companies undergoing an embryonic stage by presenting higher values. Finally, one may infer that the surveyed midsized companies seek strategies and actions given the decision or need to migrate to the mature stage and combine both types of innovations ( product and process 
and organizational). The first step requires one to understand that innovation is dynamic, open and essentially comprises entrepreneurial actions, i.e. concept, development, and marketing phases interact and are continuously influenced and may even be determined by the current market, technology and science status. .

From a pragmatic standpoint, procedural logic of the kind is implemented via strategies and internal and external actions, namely: market research and, participation in trade fairs, technical and commercial events to explore technologies and understand market movements; monitor patent banks, , journals and take part in scientific and academic events so as to access state of the art knowledge, internally encourage creativity and entrepreneurship, encourage teamwork and learning and promote the emergence of a continuous innovation culture where by focus lies in the generation of innovative solutions for the company (not necessarily by the company) and in the search for development or research partners; incorporation of academic spin-offs and acquisition of technologies from universities and to obtain innovation patents, licensing innovations whilst still attractive and so forth. In as much as future studies are concerned it is our understanding that this research may be replicated whereby detailed stratifications are performed according to technological intensity per sector and geographical location of midsized companies. This might enrich the overall analysis and subsequently promote the proposition of sectorial and regional innovation policies specifically designed for average sized companies. As to the limitations of this study, the relatively low number of valid cases may have posed impairments. To this effect, mitigation would require the application of multivariate tests such as regressions and structural equations, so as to enrich overall analysis of results.

\section{BIBLIOGRAPHIC REFERENCES}

Amit, R., \&Schoemaker, J. (1993).Strategic assets and organizational rent.Strategic Management Journal, 14, 33-46.

Barney, J. (1991). Firm resource and sustained competitive advantage.Journal of Management, 17(1), 99-120.

Barney, J. (1986). Strategic factor markets.Management Science, 32(10), 12311241.

Barney, J. (1995). Looking inside for competitive advantage.Academy Management of Executive, 9(4), 49-61. 
Bell, M., \&Pavitt, K. (1993). Technological accumulation and industrial growth: contrasts between developed and developing countries. Industrial and Corporate Change, 1(2), 157-210.

Berkhout, A., Hartmann, D., Duin, P., \&Ortt, R. (2006).Innovating the innovation process. Technology Management, 34(3), 390-404.

Besemer, S. (2000).Creative Product Analysis to Foster Innovation.Design Management Journal, 11(4), 59-64.

Bloom, N., \& Van Reenen, J. (2007). Measuring and Explaining Management Practices Across Firms and Countries. Quarterly Journal of Economics, 122(4), 1341-1408.

Chesbrough, H. (2003). Open innovation. Boston, MA: Harvard Business School Press.

Chesbrough, H., \&Crowther, A. (2006). Beyond high tech: early adopters of open innovation in other industries. R\&D Management, 36(3), 229-236.

Chesbrough, H., Vanhaverbeke, W., \& West, J. (2008).Open innovation: researching a new paradigm. Oxford: Oxford University Press

Collis, D., \& Montgomery, C. (1995).Competing on resources strategy in the 1990s.In M. H. Zack (Ed.), Knowledge and Strategy (pp. 25-40). Woburn, MA: Butterworth-Heinemann.

Cooper, R. (1992). New Prod System: The Industry Experience. Journal of Product Innovation Management, 2, 113-127.

Creswell, J. (2007). Projeto de pesquisa: métodos qualitativo, quantitativo e misto. 2. ed. Porto Alegre: Bookman. Demsetz, H. (1973). Industrial structure, market rivality and politic policy.Journal of Law Economic Organization, 16, 1-10.

Dierickx, I., \& Cool, K. (1989).Asset stock accumulation and sustainability of competitive advantage.Management Science, 35(12), 1504-1511.

Docherty, M. (2006). Primer of Open Innovation: Principles \& Practice. Visions Magazine, 2,13-17.

Dosi, G. (1982). The nature of the innovative process.In G. Dosi (Ed.), Technical change and economic theory.London: Printer Publishers.

Eisenhardt, K., \& Martin, J. (2000). Dynamic capabilities: what are they?.Strategic Management Journal, 21, 1105-1121.

Engeroff, R., \&Balestrin, A. (2008). Inovação fechada versus inovação aberta: um estudo de caso da indústria de cutelaria. Simpósio de Gestão da Inovação Tecnológica. Brasília. 
Etzkowitz, H. (2004). The evolutionoftheentrepreneurialuniversity. International Journal of Technology and Globalisation, 1(1), 64-77.

Foss, N. (1997).The resource-based perspective: an assessment and diagnosis of problems. Copenhagen: Copenhagen Business School.

Freeman, C. (1995). Innovation in a New Context.Science Technology Industry Review, 15, 49-73.

Freeman, C. (1994). The economics of technical change.Cambridge JournalofEconomics, 18, 463-514.

Freire, A (2006). Inovação: Novos Produtos, Serviços e Negócios para Portugal. Lisboa: Verbo.

Gava, R. (2007). Um Estudo Sobre a Iniciativa De Se Constituir Um Sistema De Inovação Em Nível De Firma No Mercado Brasileiro De Telecomunicações. Simpósio de Gestão da Inovação Tecnológica. Rio de Janeiro.

Gil, A. (2002). Métodos e técnicas de pesquisa social. 4 ed. São Paulo: Atlas.

Hair, J., Anderson, R., Tatham, R., \& Black, W. (2005).Análise multivariada de dados. 5.ed. Porto Alegre: Bookman.

Härdle, W., \&Simar, L. (2007).Applied multivariate statistical analysis. 2 ed. Berlin: Springer.

Helfat, E., Finkelstein, S., Mitchell, W., Peteraf, M., Singh, H., \&Tecee, D. et al. (2007).Dynamic Capabilities: Understanding Strategic Change In Organizations. Oxford: Blackwell Publishing.

Kline, S, \& Rosenberg, N. (1986).An Overview of Innovation. In N. Rosenberg (Org), The Positive Sum Strategy. Washington, DC: National Academy of Press.

Leydesdorff, L., Dolfsma, W., \& Panne, G. (2006). Measuring the Knowledge Base of an Economy in terms of Triple-Helix Relations among Technology, Organization, and Territory.Research Policy,35(2), 181-199.

Leydesdorff, L., \&Meyer, M. (2006).Triple Helix indicators of knowledge-based innovation systems: Introduction to the special issue. Research Policy, 35(10), 1441-1449.

Lippman, S., \&Rumelt, R. (1982). Uncertain imitability: an analysis of interfirm differences in efficiency under competition. The Bell JournalofEconomics. 13, 418-438.

Lima, M. (2008). Monografia: a engenharia da produção acadêmica. 2. ed. São Paulo: Saraiva.

Lundvall, B. (1992). National systems of innovation: towards a theory of innovation and interactive learning. Londres: Pinter. 
Montgomery, D. (2000). Design and Analysis of Experiments. $5^{\mathrm{a}}$ ed. Nova York: John Wiley \& Sons.

Morse, J. M. (2003). Principles of mixed methods and multimethod research design. In: TASHAKKORI, A.; TEDDLIE, C. Handbook of mixed methods in social $\&$ behavioral research. Thousand Oaks, CA: Sage Publications.

Nelson, R., \&Winter, S. (1977). In search of useful theory of innovation.Research Policy, 6, 36- 76.

Organization for Economic Cooperation and Development - OECD (2005).Os/o Manual: Guidelines for Collecting and interpreting innovation data. 3 ed. OECD Publishing.

Pagano, M., \&Gauvreau, K. (2004). Princípios de bioestatística. 2a ed. São Paulo: EditoraManole.

Penrose, E. (1959). The theory of the growth of the firm. Oxford: Basil Blackwell. Peteraf, M. (1993). The cornerstones of competitive advantage: a resourcebased view. Strategic Management Journal, 14(3), 179-191.

Pisano, G. (2000). In search of dynamic capabilities.In Dosi, G., Nelson, R., \&Winter, S. The nature and dynamics of organizational capabilities.Oxford: Oxford Univesity Press.

Porto, G. (2000). A decisão empresarial de desenvolvimento tecnológico por meio da cooperação empresa-universidade. (Tese de doutorado em Administração, Faculdade de Economia, Administração e Contabilidade, Departamento de Administração, Universidade de São Paulo, São Paulo, 2000).

Prahalad, C., \& Hamel, G. (1990). The Core Competence of the Corporation.Harvard Business Review, 79-91.

Reed, R., \&Defillippi, R. (1990).Causal ambiguity, barriers to imitation, and sustainable competitive advantage.Academy of Management Review, 15, 88-102. Rumelt, R. (1984). Towards a strategic theory of the firm. In: Lamb, R. (ed.). Competitive Strategic Management. Englewood Cliffs, NJ: Prentice-Hall.

Rumelt, R. (1987). Theory, strategic and entrepreneurship. In: Teece, D.(ed.). The competitive challenge. Cambridge: Ballinger Publishing Company.

Sanchez, R. (1996). Management at the point of inflection: systems, complexity and competence theory. Long Range Planning, 30(6), 939-946.

Schumpeter, J. (1988). Teoria do desenvolvimento econômico. Tradução Maria Silvia Possas. 3 ed. São Paulo: Nova Cultural. 
Teece, D. (1986). Profiting from technological innovation: Implications for integration, collaboration, licensing and public policy.Research Policy, 15, 285305.

Teece, D. (1980). Economics of scope and the scope of the enterprise.Journal Economic Behavior and Organization, 1, 223-247.

Teece, D. (1982). Towards an economic theory of the multiproduct firm.Journal Economic Behavior Organization, 3, 39-63.

Teece, D. (2007). Explicating dynamic capabilities: the nature and microfoundations of (sustainable) enterprise performance.Strategic Management Journal, 28, 1319-1350.

Teece, D., Pisano, G., \&Shuen, A. (1997).Dynamic capabilities and strategic management.Strategic Management Journal, 18(7), 509-533.

Teece, D., Pisano, G. (1994). The dynamic capabilities of firms: an introduction. Industrial and Corporate Change, 3(3), 537-556.

Tidd, J., Bessant, J., \&Pavitt, K. (2003). Gestão da Inovação. Integração de mudanças Tecnológicas, de mercado e organizacionais. Lisboa: Monitor.

Van Der Meer, H. (2007). Open Innovation - The Dutch Treat: Challenges in Thinking in Business Models. Creativity and Innovation Management, 16(2), 192202.

Velde, M. V. D. et al. (2004) Guide to management research methods. Malden, MA: Blackwell Publishing. Wernerfelt, B. (1984). A resource based view of the firm. Strategic Management Journal, 5, 171-180.

West, J., \& Gallagher, S. (2008). Patterns of Open Innovation in Open Source Software. In Chesbrough, H., Vanhaverbeke, W., \& West, J. Open Innovation: researching a new paradigm. New York: Oxford.

Winter, S. (1988). Knowledge and competence as strategic assets. In.: Teece, D. (ed.).The competitive Challenge. Cambridge, MA: Ballinger, 159-184. 